\title{
Stable isotope enrichment in muscle, liver, and whole fish tissues of brown-marbled groupers (Epinephelus fuscoguttatus)
}

\author{
Gang Chen ${ }^{1,2}$, Hui Zhou', Duoliang Ji ${ }^{1}$ and Binhe Gu${ }^{1 *}$
}

\begin{abstract}
Introduction: The purpose of this study was to assess enrichments in stable carbon and nitrogen isotopes $\left(\delta^{13} \mathrm{C}\right.$ and $\delta^{15} \mathrm{~N}$ ) in brown-marbled groupers (Epinephelus fuscoguttatus), a marine fish that has been widely used in aquaculture. Stable isotope analysis has been used to evaluate dietary sources and the trophic position of fish. There is the need to better understand the pattern of isotope enrichment between consumers and diets under laboratory conditions.

Methods: We studied the changes in stable carbon and nitrogen isotopes of juvenile brown-marbled groupers during a feeding experiment in 2009. Fish were grown in aquaria and fed a sole source of protein for 56 days and analyzed for $\delta^{13} \mathrm{C}$ and $\delta^{15} \mathrm{~N}$ ratios in whole fish, muscle, and liver tissues.

Results: At the end of the 56-day feeding experiment, fish grew to an average of $55.6 \mathrm{~g}$ from an average of $22.5 \mathrm{~g}$. Compared to the dietary isotope compositions, whole fish and muscle tissues of the juvenile groupers were enriched in $\delta^{13} \mathrm{C}$ by 1.6 and $0.5 \%$, while the liver was depleted by $1.3 \%$. The $\delta^{15} \mathrm{~N}$ enrichments were $1.6 \%$ for whole fish, $1.3 \%$ for muscle, and $1.0 \%$ for liver. Except for liver, $\delta^{15} \mathrm{~N}$ isotope values increased significantly with time.

Conclusions: The small change in $\delta^{13} \mathrm{C}$ between the diet and fish suggests that little isotope alteration is occurring during the assimilation of dietary carbon. This provides a basis for estimates of the importance of different sources of dietary components when contrasted with the isotope values from a formulated diet with known isotope values of the different components. The smaller than expected $\delta^{15} \mathrm{~N}$ enrichment in all tissue suggests that isotope values from a wild fish sample may not always reach isotope equilibrium with the current diet, and an inference about recent dietary sources and an estimate of the consumer's trophic position should be evaluated with caution.
\end{abstract}

Keywords: Stable isotopes, Diet shift, Fish, Isotope enrichment

\section{Introduction}

Carbon and nitrogen stable isotopes $\left(\delta^{13} \mathrm{C}\right.$ and $\left.\delta^{15} \mathrm{~N}\right)$ are increasingly used to evaluate the relative contributions of different food sources and the trophic position of fish (Anderson et al. 1987; Lochman and Phillips 1996; Gu et al. 1996a, b; Gamboa-Delgado et al. 2008). Because isotope compositions reflect the organic compounds that have been incorporated into the bodies of consumers, the measurements of $\delta^{13} \mathrm{C}$ and $\delta^{15} \mathrm{~N}$ provide insightful information on the dietary component assimilated by the consumers. At the

\footnotetext{
* Correspondence: gubinhe@gmail.com

'College of Fishery, Guangdong Ocean University, Zhanjiang 524025, China Full list of author information is available at the end of the article
}

same time, conventional studies such as feeding observations or gut content analyses reveal only the materials ingested and not necessarily those assimilated by the consumers. These approaches can also be labor intensive and timeconsuming while providing little information on the sources of energy and nutrients for animal growth (Bitterlich and Gnaiger 1984; Gu et al. 1996a, b).

The use of stable isotope analysis in trophic ecology is based on the premise that the $\delta^{13} \mathrm{C}$ and $\delta^{15} \mathrm{~N}$ values of consumers reflect those of the assimilated diet and that the alteration of isotope compositions during the assimilation of food by consumers can be followed in a predicable manner (DeNiro and Epstein 1978, 1981; Minagawa 
and Wada 1984; Post 2002). Isotope enrichment in consumers takes place during the assimilation of carbon and nitrogen from the diet. A review of the literature indicates that the average isotope enrichment during each trophic transfer is $0.5 \%$ or for $\delta^{13} \mathrm{C}$ and $3.4 \%$ or $\delta^{15} \mathrm{~N}$, but with large variations in both stable isotopes (Post 2002). These data are largely derived from field studies with many unknown and uncontrolled factors such as food sources (Gu et al. 1996a, b; Post 2002) and differences in growth rate, age, and food quality, which may affect the magnitude of isotope fractionation. Muscle tissue of fish has been widely used to represent the whole fish isotope characteristic. However, previous and current studies also indicate wide variations in isotope composition among consumer tissues (DeNiro and Epstein 1978, 1981; Tieszen et al. 1983; Pinnegar and Polunin 1999; Miller 2006). More studies are needed to validate the use of a certain tissue type during a food web study to establish the precise trophic relationship between consumers and their diets.

This study was designed to analyze the magnitude of isotope enrichment in fish and thus to provide the basis for a better understanding of the dietary sources and trophic position of fish. The experiment utilized brownmarbled groupers, Epinephelus fuscoguttatus, a carnivorous fish widely distributed in the subtropical and tropical marine regions and grown as a high quality human food in Southeast Asia.

\section{Methods}

The experiment was conducted at the aquaculture facility of Long Hai Tian Science Garden, Dong Hai Island, Guangdong, China, between July and October 2009. The experimental units were plastic aquaria with the dimensions of $70 \times 50 \times 70 \mathrm{~cm}$ (length $\times$ width $\times$ height). Each aquarium was filled with continuously aerated natural seawater prefiltered using a sand medium. Water quality was monitored following the standard methods (APHA 1998). The experiment was conducted indoors using a natural dark:light cycle. The fish diet was of trash fish (Engraulis ringens) powder imported from Peru, which was formed into pellets. The composition of the formulated pellets is presented in Table 1. The average stable isotope values of the diet were $16.4 \%$ for $\delta^{15} \mathrm{~N}$ and $-20.4 \%$ for $\delta^{13} \mathrm{C}$ (Table 1 ).

Newly hatched larval fish were obtained from the Guangdong Ocean University hatchery and raised in a large cement tank with a commercial feed. After reaching an average weight of $22.5 \pm 3.2 \mathrm{~g}$, the fish were transferred to six aquaria stocked with 12 fish per aquarium. Fish were fed with the formulated pellets as the only protein source twice daily at 0900 and 1300 local time. Samples for stable isotope analysis were taken at day 0 , $3,7,14,28,42$, and 56 . Prior to sampling, all fish were
Table 1 Chemical composition and stable isotope values of the diet (trash fish) used in the current experiment

\begin{tabular}{lc}
\hline Component & Values \\
\hline Crude protein (\% dry mass) & 50.17 \\
Crude fat (\% dry mass) & 10.32 \\
Crude fiber (\% dry mass) & 5.6 \\
Gross energy (k/g) & 19.25 \\
$\delta^{13} \mathrm{C}(\%)$ & -20.4 \\
$\delta^{15} \mathrm{~N}(\%)$ & 16.4 \\
\hline
\end{tabular}

starved for $24 \mathrm{~h}$ to expunge the food content of their stomachs and intestines. All fish from a randomly selected aquarium were harvested during each sampling event. Three individuals were used for whole fish, muscle, and liver ( $n=9$ fish), respectively. The remaining fish served as backup alternates. For whole fish, the entire fish was cut into several pieces. For muscle and liver tissue, the dorsal muscle tissue and liver were removed from each fish and washed with deionized water to remove blood. Fish feces were collected by siphoning from the bottom of the aquarium. All samples were dried at $70^{\circ} \mathrm{C}$ and ground to a fine power.

For stable isotope analysis, about $1 \mathrm{mg}$ of the sample was loaded into a tin capsule and shipped to the Stable Isotope Facility of the University of California, Davis for ${ }^{13} \mathrm{C}$ and ${ }^{15} \mathrm{~N}$ analysis using a PDZ Europa ANCA-GSL elemental analyzer interfaced to a PDZ Europa 20-20 isotope ratio mass spectrometer (Sercon, Cheshire, UK). Samples were combusted at $1,000^{\circ} \mathrm{C}$ in a reactor packed with chromium oxide and silvered cobaltous/cobaltic oxide. During analysis, samples were interspersed with several replicates of at least two different laboratory standards. The long term standard deviation is $0.2 \%$ for ${ }^{13} \mathrm{C}$ and $0.3 \%$ for ${ }^{15} \mathrm{~N}$. The heavy to light isotope ratios $\left({ }^{13} \mathrm{C} /\right.$ ${ }^{12} \mathrm{C}$ and $\left.{ }^{15} \mathrm{~N} /{ }^{14} \mathrm{~N}\right)$ are reported as the conventional delta notation $(\delta)$ defined as $\delta \mathrm{X}=\left[\left(\mathrm{R}_{\text {sample }} / \mathrm{R}_{\text {standard }}\right)-1\right] \times 1,000$, where $\mathrm{X}$ is ${ }^{13} \mathrm{C}$ or ${ }^{15} \mathrm{~N}$ and $\mathrm{R}$ is the ratio of ${ }^{13} \mathrm{C} /{ }^{12} \mathrm{C}$ or ${ }^{15} \mathrm{~N} /{ }^{14} \mathrm{~N}$. Isotopic ratios are expressed relative to VPDB (Vienna Pee Dee belemnite) for $\delta^{13} \mathrm{C}$ and to atmospheric nitrogen for $\delta^{15} \mathrm{~N}$.

\section{Results}

During the experimental period, water temperature ranged from 24 to $28^{\circ} \mathrm{C}$, salinity from 29 to $31 \%$, $\mathrm{pH}$ from 7.9 to 8.2, dissolved oxygen was $>6 \mathrm{mg} / \mathrm{L}$, ammonium $<0.02 \mathrm{mg} /$ $\mathrm{L}$, and nitrate $<2.0 \mathrm{mg} / \mathrm{L}$. At the end of the experiment, fish grew to an average of $55.6 \mathrm{~g}$ from an average of $22.5 \mathrm{~g}$, more than doubling their initial weight (Table 2). The average growth rate $(k)$ of fish was calculated to be 0.023 .

Changes in both $\delta^{13} \mathrm{C}$ and $\delta^{15} \mathrm{~N}$ values of whole fish, muscle, and liver tissues during the experimental period 
Table 2 Body length, total length and wet weight of brown-marbled groupers before and during the experimental period

\begin{tabular}{|c|c|c|c|c|c|c|c|}
\hline \multirow{2}{*}{$\begin{array}{c}\text { Time } \\
\text { Day }\end{array}$} & \multicolumn{2}{|c|}{$\begin{array}{l}\text { Body length } \\
(\mathrm{cm})\end{array}$} & \multicolumn{2}{|c|}{$\begin{array}{l}\text { Total length } \\
(\mathrm{cm})\end{array}$} & \multicolumn{2}{|c|}{$\begin{array}{l}\text { Wet weight } \\
\text { (g) }\end{array}$} & \multirow[t]{2}{*}{$\begin{array}{l}\text { Sample } \\
\text { number }\end{array}$} \\
\hline & Mean & SD & Mean & SD & Mean & SD & \\
\hline Before & 9.0 & 0.6 & 10.7 & 0.7 & 22.5 & 3.8 & 10 \\
\hline 3 & 9.1 & 0.5 & 10.7 & 0.4 & 24.5 & 3.8 & 10 \\
\hline 7 & 9.4 & 0.5 & 11.6 & 0.9 & 31.1 & 5.1 & 10 \\
\hline 14 & 10.7 & 0.4 & 12.8 & 0.5 & 35.4 & 5.1 & 10 \\
\hline 28 & 11.6 & 0.6 & 13.4 & 0.6 & 42.7 & 5.9 & 10 \\
\hline 42 & 12.7 & 0.6 & 14.4 & 0.8 & 45.6 & 7.5 & 10 \\
\hline 56 & 10.5 & 1.2 & 13.6 & 1.5 & 55.6 & 14.1 & 10 \\
\hline
\end{tabular}

are presented in Figure 1. The initial whole fish $\delta^{13} \mathrm{C}$ value $(-21.1 \%$ o $)$ was below the dietary value $(-20.4 \%$ o and increased linearly to $-18.8 \%$ by day 56 (Figure $1 \mathrm{~A}$ ). In contrast, the initial muscle $\delta^{13} \mathrm{C}$ value $(-18.6 \%$ ) was above the dietary value and increased to $-17.5 \%$ by day
56 (Figure 1B). The initial liver $\delta^{13} \mathrm{C}$ value $(-23.2 \%$ ) was well below the dietary value and reached a peak value $(-21.3 \%)$ at day 28 and then slightly decreased and increased at day 42 and day 56, respectively (Figure 1C). At the end of the experiment, whole fish and muscle tissue of the juvenile groupers were enriched in $\delta^{13} \mathrm{C}$ by 1.6 and $0.5 \%$ while the liver was depleted by $1.3 \%$. All regression models showed significant increases in $\delta^{13} \mathrm{C}$ values during the experimental period.

The initial $\delta^{15} \mathrm{~N}$ values of whole fish, muscle, and liver tissues were all below the dietary value and increased linearly as fish grew (Figure 1). The whole fish $\delta^{15} \mathrm{~N}$ value increased from $15.7 \%$ at day 0 to $18.0 \%$ at day 56 (Figure 1D). The muscle $\delta^{15} \mathrm{~N}$ value increased from $16.1 \%$ at day 0 , reached its peak value $(18.1 \%$ ) at day 42 , and then decreased slightly to $17.8 \%$ at day 56 (Figure 1E). The initial liver $\delta^{15} \mathrm{~N}$ value $(14.5 \%$ ) was well below the dietary value and remained little changed between days 3 and 27 before rapidly increasing above the dietary value during the final two sampling dates (Figure 1F). The $\delta^{15} \mathrm{~N}$ enrichments were $1.6 \%$ for whole fish, $1.3 \%$ for muscle, and $1.0 \%$ for liver. Except for

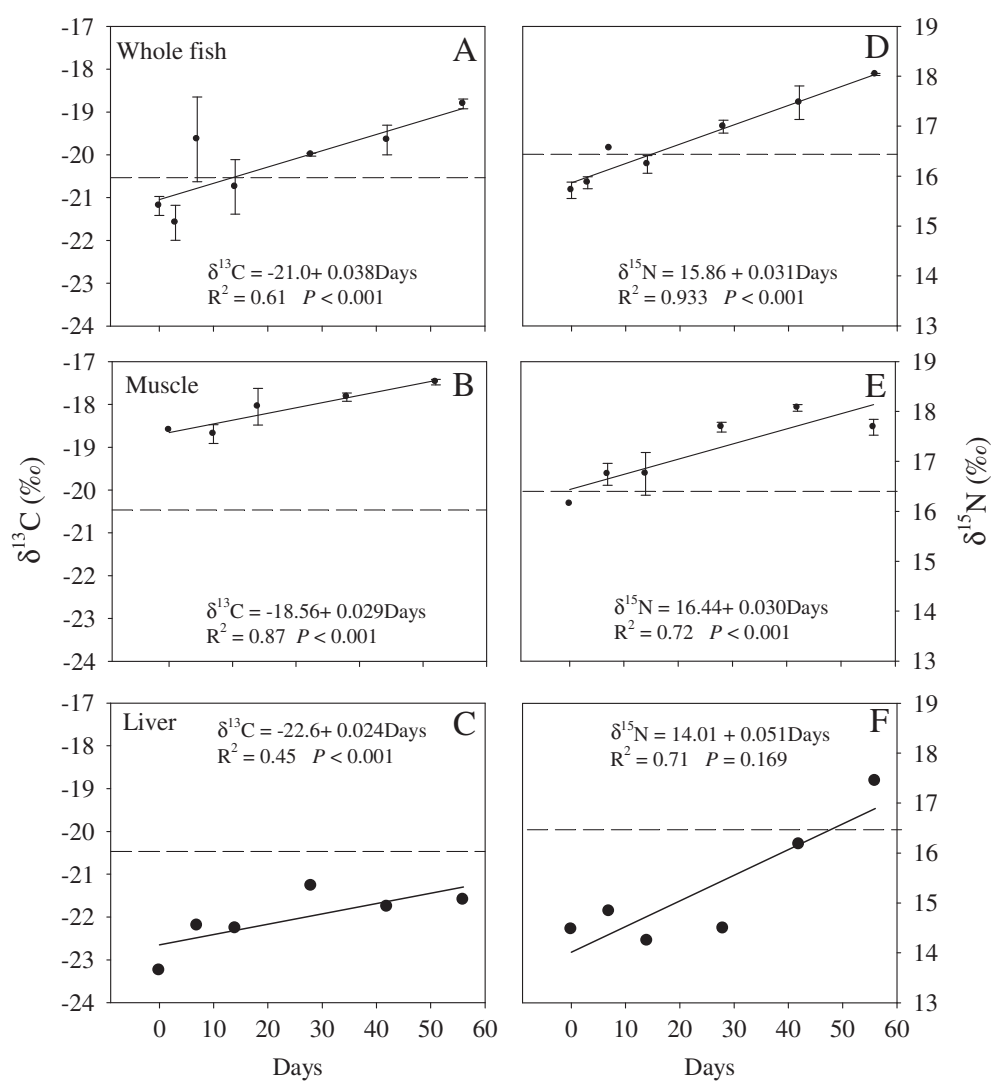

Figure 1 Changes in $\delta^{13} \mathrm{C}$ and $\delta^{15} \mathrm{~N}$ for whole fish, muscle, and liver tissues of juvenile brown-marbled groupers during the 56-day experimental period. The dashed lines represent the dietary values of $\delta^{13} \mathrm{C}\left(-20.4 \%\right.$ ) or $\delta^{15} \mathrm{~N}(16.4 \%)$. 
liver, regression models for whole fish and muscle tissue showed significant increases in $\delta^{15} \mathrm{~N}$ values during the experimental period.

\section{Discussion and conclusions}

Previous studies have shown various magnitudes of isotope enrichment in whole animals and individual tissues such as muscle, liver, kidney, blood, and hair (DeNiro and Epstein 1978, 1981; Tieszen et al. 1983; Pinnegar and Polunin 1999; Miller 2006). Isotope enrichments were the result of preferential retention of the heavy isotopes ${ }^{13} \mathrm{C}$ and ${ }^{15} \mathrm{~N}$ during assimilation of dietary carbon and nitrogen (DeNiro and Epstein 1978, 1981). This was also confirmed in this experiment by noting that the feces were isotopically depleted (Table 3), leading to ${ }^{13} \mathrm{C}$ and ${ }^{15} \mathrm{~N}$ enrichment in the tissues of juvenile groupers. Our results also show that, compared to the dietary isotope value, liver was depleted in ${ }^{13} \mathrm{C}$. This is likely attributed to lipid storage in the liver that is depleted in ${ }^{13} \mathrm{C}$.

Various factors have been proposed to account for the differences in $\delta^{13} \mathrm{C}$ and $\delta^{15} \mathrm{~N}$ values between animal tissues and their diet. Earlier studies showed that different individuals of a species differ in isotope fractionation when fed the same diet, but that isotope fractionation differs more between species than among individuals of the same species (DeNiro and Epstein 1978, 1981). Our results also showed differing isotope enrichments or depletions compared with the dietary $\delta^{13} \mathrm{C}$. However, in general, the $\delta^{13} \mathrm{C}$ enrichment of the juvenile groupers was less than $2 \%$. The muscle tissue of the juvenile groupers was enriched by $0.5 \%$, nearly identical to the reported average enrichment (Post 2002). These results suggest that muscle tissue is the most consistent proxy for carbon isotope fractionation when compared to the findings of many previous studies on fish (Hesslein et al. 1993; Pinnegar and Polunin 1999).

Our results also show that the $\delta^{15} \mathrm{~N}$ enrichment of muscle and liver tissues or whole fish is only $1.0-1.6 \%$, which is far below the reported average value (3.4\%). Several mechanisms may explain this discrepancy. First,

\begin{tabular}{|c|c|c|c|c|c|}
\hline Day & $\delta^{13} \mathrm{C}(\%)$ & $\delta^{15} \mathrm{~N}(\%)$ & $\% \mathrm{~N}$ & $\% \mathrm{C}$ & Sample number \\
\hline 0 & $-21.9(0.2)$ & $10.3(0.0)$ & $2.2(0.2)$ & $23.1(2.0)$ & 4 \\
\hline 7 & $-22.3(0.6)$ & $15.5(0.5)$ & $1.9(0.4)$ & $19.9(3.1)$ & 5 \\
\hline 14 & $-21.5(0.3)$ & $14.8(0.8)$ & $1.9(0.3)$ & $17.7(3.3)$ & 5 \\
\hline 28 & $-21.2(0.6)$ & $14.8(0.9)$ & $1.8(0.3)$ & $18.0(4.0)$ & 4 \\
\hline 42 & $-21.6(0.3)$ & $14.3(0.2)$ & $1.8(0.1)$ & $18.0(0.7)$ & 2 \\
\hline 56 & -20.1 & 18 & 3.3 & 20.6 & 1 \\
\hline
\end{tabular}

different consumers may have their intrinsic isotope fractionation during assimilation of protein. For example, Hesslein et al. (1993) found a maximum value of 3.0 of $\delta^{15} \mathrm{~N}$ enrichment for broad white fish (Coregonus nasus). Pinnegar and Polunin (1999) reported $\delta^{15} \mathrm{~N}$ enrichment in rainbow trout (Oncorhynchus mykiss) of $2.6 \%$. Second, consumers might assimilate a specific dietary component isotopically different from the whole diet, especially when they have access to a variety of diets in nature or are fed a formulated diet that is made from several sources of protein (Robbins et al. 2005a, b). This is not the case in our study because only a single source of protein was used. Third, dietary nutritional quality (Robbins et al. 2005a, b) and growth conditions (Hobson et al. 1993; Gaye-Siessegger et al. 2004) may also affect the isotope compositions of the consumers. These cannot be applied to our study because the formulated diet was high in nutritional value (Table 1), and good water quality was maintained during the experimental period. Lastly, it is also likely that the consumers had not reached isotopic equilibrium with the new diet during this study. This is evident from the linear relationship between time and the isotope values of the liver tissue and whole fish tissues (Figure 1), which never attained asymptotic values for either $\delta^{13} \mathrm{C}$ or $\delta^{15} \mathrm{~N}$. It appears that the muscle $\delta^{15} \mathrm{~N}$ likely reached isotope equilibrium, but the experimental period was not long enough to provide sufficient data to confirm the asymptotic isotope stage. This finding is important when the measured values are used to determine the trophic position of fish that may switch diets due to migration or growth or that are affected by rapid changes in $\delta^{13} \mathrm{C}$ and $\delta^{15} \mathrm{~N}$ of the dietary organisms over a seasonal cycle ( $\mathrm{Gu}$ 2009; Gu et al. 2011).

Results from this experiment have important implications for the studies of animal dietary composition and trophic positions. The small change in $\delta^{13} \mathrm{C}$ between the diet and fish suggests that little isotope alteration is occurring during the assimilation of dietary carbon. This provides the basis for the estimates of the importance of different sources of dietary components when contrasted with the isotope values from a formulated diet with known isotope values of the different components (Lochman and Phillips 1996; Gamboa-Delgado et al. 2008). The data from this study also suggest that isotope values from a wild fish sample may not reach isotope equilibrium with the current diet and hence an inference about recent dietary sources or trophic position should be evaluated with caution because the isotope values are likely the results of previous and current dietary uptake. This is especially true in aquatic ecosystems where environmental changes or fish migration often result in a shift in diet or changes in the isotope composition of dietary organisms such as plankton (see review by $\mathrm{Gu}$ 2009; Gu et al. 2011). 


\section{Competing interests}

The authors declare that they have no competing interests.

\section{Authors' contributions}

GC, $\mathrm{HZ}$ and BG designed the study; $\mathrm{HZ}$ and DJ oversaw the experiment; BG drafted the manuscript. All authors read and commented on the manuscript.

\section{Acknowledgments}

We appreciate Dr. Xiaohui Dong for assistance with the design and formulation of the formulated pellets. This study was supported by grants A200608C02, A200908D03, 2006B20201059, and 2009B020308005 from several funding agencies of the Guangdong Province government, China. Dr. Thomas Dreschel provided language improvements on the final draft of this manuscript.

\section{Author details}

${ }^{1}$ College of Fishery, Guangdong Ocean University, Zhanjiang 524025, China. ${ }^{2}$ Guangdong South China Sea Key Laboratory of Aquaculture for Aquatic Economic Animals, Zhanjiang524025, China.

Received: 12 May 2012 Accepted: 22 June 2012

Published: 12 July 2012

\section{References}

Anderson R, Parker PL, Lawrence A (1987) $\mathrm{A}^{13} \mathrm{C} /{ }^{12} \mathrm{C}$ tracer study of the utilization of presented feed by a commercially important shrimp Penaeus vannamei in a pond growout system. J World Aquacult Soc 18:148-155

APHA (1998) Standard methods for the examination of water and wastewater, 20th edn. American Public Health Association, American Water Works Association and Water Pollution Control Federation, Washington DC

Bitterlich G, Gnaiger E (1984) Phytoplanktivorous or omnivorous fish? Digestibility of zooplankton by silver carp, Hypophthalmichthys molitrix (Val.). Aquaculture 40:261-263

DeNiro MJ, Epstein S (1978) Influence of diet on the distribution of carbon isotopes in animals. Geochim Cosmochim Acta 42:495-506

DeNiro MJ, Epstein S (1981) Influence of diet on the distribution of nitrogen isotopes in animals. Geochim Cosmochim Acta 45:341-351

Gamboa-Delgado J, Cañvate JP, Zerolo R, Le Vay L (2008) Natural carbon stable isotope ratios as indicators of the relative contribution of live and inert diets to growth in larval Senegalese sole (Solea senegalensis). Aquaculture 280:190-197

Gaye-Siessegger J, Focken U, Muetzel S, Abel H, Becker K (2004) Feeding level and individual metabolic rate affect $\delta^{13} \mathrm{C}$ and $\delta^{15} \mathrm{~N}$ values in carp: implications for food web studies. Oecologia 138:175-183

Gu B (2009) Variations and controls of nitrogen stable isotopes in particulate organic matter of lakes. Oecologia 160:421-431

Gu B, Schelske CL, Hoyer MV (1996a) Stable isotopes of carbon and nitrogen as indicators of diet and trophic structure of the fish community in a shallow hypereutrophic lake. J Fish Biol 49:1233-1243

Gu B, Schell DM, Huang X, Yie F (1996b) Stable carbon and nitrogen isotope evidence for dietary overlap between two planktivorous fish in aquaculture ponds. Can J Fish Aquat Sci 53:2814-2818

Gu B, Schelske CL, Waters MN (2011) Patterns and controls of seasonal variability of carbon stable isotopes of particulate organic matter in lakes. Oecologia 165:1083-1094

Hesslein RH, Hallard KA, Ramlal P (1993) Replacement of sulfur, carbon, and nitrogen in tissue of growing broad whitefish (Coregonus nasus) in response to a change in diet traced by ${ }^{34} \mathrm{~S},{ }^{13} \mathrm{C}$, and ${ }^{15} \mathrm{~N}$. Can J Fish Aquat Sci 50:20712076

Hobson KA, Alisauskas RT, Clark RG (1993) Stable-nitrogen isotope enrichment in avian tissues due to fasting and nutritional stress: implications for isotopic analyses of diet. Condor 95:388-394

Lochman R, Phillips H (1996) Stable isotopic evaluation of the relative assimilation of natural and artificial foods by golden shiners Notemigonus crysoleucas in ponds. J World Aquacult Soc 27:168-177

Miller TW (2006) Tissue-specific response of ${ }^{15} \mathrm{~N}$ in adult Pacific herring (Clupea pallasi) following an isotopic shift in diet. Env Biol Fish 76:177-189

Minagawa M, Wada $\mathrm{E}$ (1984) Stepwise enrichment of ${ }^{15} \mathrm{~N}$ along food chains: further evidence and the relation between $\delta^{15} \mathrm{~N}$ and animal age. Geochim Cosmochim Acta 48:1135-1140
Pinnegar JK, Polunin NVC (1999) Differential fractionation of ${ }^{13} \mathrm{C}$ and ${ }^{15} \mathrm{~N}$ among fish tissues: implications for the study of trophic interactions. Funct Ecol $13: 225-231$

Post DM (2002) Using stable isotopes to estimate trophic position: models, methods, and assumptions. Ecology 83:703-718

Robbins CT, Felicetti LA, Sponheimer M (2005a) The effect of dietary protein quality on nitrogen isotope discrimination in mammals and birds. Oecologia 144:534-540

Robbins CT, Felicetti LA, Florin TF (2005b) The impact of protein quality on stable nitrogen isotope ratio discrimination and assimilated diet estimation. Oecologia 162:571-579

Tieszen LL, Boutton TW, Tesdahl KG, Slade NA (1983) Fractionation and turnover of stable carbon isotopes in animal tissues: implications for ${ }^{13} \mathrm{C}$ analysis of diet. Oecologia 57:32-37

doi:10.1186/2192-1709-1-7

Cite this article as: Chen et al:: Stable isotope enrichment in muscle, liver, and whole fish tissues of brown-marbled groupers (Epinephelus fuscoguttatus). Ecological Processes 2012 1:7.

\section{Submit your manuscript to a SpringerOpen ${ }^{\circ}$ journal and benefit from:}

- Convenient online submission

- Rigorous peer review

- Immediate publication on acceptance

- Open access: articles freely available online

- High visibility within the field

- Retaining the copyright to your article

Submit your next manuscript at $>$ springeropen.com 